\title{
KETERLIBATAN ORANG TUA DALAM PEMBELAJARAN ANAK USIA DINI SELAMA BELAJAR DARI RUMAH DI MASA PANDEMI COVID-19
}

\begin{abstract}
Jane Gresia Akollo, Meike Elsa Toisuta
Dosen IAKN Ambon

ezechiel.mom@gmail.com, meikeelsa@gmail.com

Abstrack

In children learning process that is conducted from home during the Covid-19 pandemic, parents must function as "teachers". As the 'teachers', parents must prepare themselves, starting from reading books, participating in webinars, following learning videos or videos of children's creativity activities in order to nourish their intellectuals with various information and knowledge. This study employs a qualitative approach with a case study method on 10 parents (father or mother) who had early childhood (5-6 years) at PAUD Rafflesia Arnolis, Kayu Tiga, Soya Village Ambon City. The data were obtained through interviews and documentation. The result of this study reveal some foms of parental involvement namely there is a communication between parents and teacher, accompany and help children learn as well as privide learning facilities. In addition, there are several positive things created between parents and children, such as the closeness of parents and children, parents can follow and know about children's learning development and parents are enriched intellectually and creatively while being 'teachers' for children at home. The benefit of the research is that the parents realize how important it is for them to be involved in their childrens' learning process and recognize the forms of involvement. Thus, parents can improve the quality and intensity of their children's learning involvement at home during the Covid-19 pandemic.
\end{abstract}

Keywords: parental involvement, early childhood, learning from home

\section{Pengantar}

Dalam upaya pencegahan penyebaran covid-19 maka pemerintah mengeluarkan Surat Edaran Nomor 4 Tahun 2020 tentang Pelaksanaan Kebijakan Pendidikan dalam Masa Darurat Penyebaran Coronavirus Disease (Covid-19) antara lain ketentuan belajar dari rumah melalui pembelajaran daring/jarak jauh dilaksanakan untuk memberikan pengalaman belajar yang bermakna bagi siswa, (Mendikbud, 2020). Hal ini bertujuan untuk menghindari kontak fisik ataupun kerumunan orang dalam jumlah banyak guna memutus mata rantai penyebaran virus corona agar penularannya tidak meluas dalam lingkungan pendidikan. Atas dasar ini maka seluruh jenjang pendidikan baik swasta ataupun pemerintah dialihkan dengan belajar dari rumah.

Menteri Pendidikan dan Kebudayaan (Mendikbud) Nadiem Anwar Makarim menjelaskan pembelajaran daring/jarak jauh difokuskan pada peningkatan pemahaman siswa mengenai virus korona dan wabah Covid-19. Adapun aktivitas dan tugas pembelajaran dapat bervariasi antar siswa, sesuai minat dan kondisi masing-masing, termasuk dalam hal kesenjangan akses/fasilitas belajar di rumah. Kemudian, bukti atau produk aktivitas belajar diberi umpan balik yang bersifat kualitatif dan berguna dari guru, tanpa diharuskan memberi skor/nilai kuantitatif (Okenews, 2020, https://news. okezone.com/read/2020/03/25/65/2188872/ar ti-belajar-di-rumah-di-tengah-wabah-viruscorona?page $=1$. Diakses pada tanggal 4 September 2020 Pukul 02.30 WIT).

Situasi ini bukan mudah bagi setiap lembaga pendidikan. Sebab, proses pembelajaran yang biasanya dilakukan dengan cara tatap muka harus digantikan segera dengan belajar dari rumah. Untuk menjembatani itu maka pembelajaran pun dilakukan secara daring (dalam jaringan). Metode pembelajaran ini pun kemudian menyisakan banyak keluhan yang beragam, dari tidak memiliki Handphone (Hp) android dan laptop, keterbatasan ekonomi keluarga dalam pembelian paket data internet, 
jaringan internet yang masih belum merata di daerah-daerah tertentu di Indonesia serta keterbatasan pengetahuan guru tentang penggunaan teknologi informasi.

Aji (2020) menguraikan tentang banyak varians masalah yang menghambat terlaksananya efektivitas pembelajaran metode daring diantaranya adalah: 1) keterbatasan penguasaan teknologi informasi oleh guru dan siswa; 2) sarana dan prasarana yang kurang memadai; 3) akses internet yang terbatas dan belum merata di daerahdaerah; dan 4) kurang siapnya penyediaan anggaran dalam pembelian kuota internet. Ada dilema dalam pemanfaatan media daring, ketika menteri pendidikan memberikan semangat produktivitas harus melaju, namun disisi lain kecakapan dan kemampuan finansial guru dan siswa belum melaju ke arah yang sama.

Dalam wawancara yang dilakukan via telp dan viceo call dengan Kepala Sekolah dan Guru PAUD Arnolis Raflesia Kayu Tiga Ambon tanggal 6 Agustus 2020 Pukul 11.15 terhadap kepala sekolah dan guru PAUD ditemukan bahwa belajar secara daring tidak dapat dilaksanakan oleh pihak sekolah, se-=bab masih ada orang tua yang minim pengetahuan tentang mengakses inter-net, tidak meratanya kemampuan ekonomi keluarga dalam membeli paket data internet dan tidak semua orang tua siswa yang memiliki Hp sebagai salah satu fasilitas belajar online. Maka kebijakan pihak sekolah dan juga disetujui oleh orangtua adalah siswa belajar dari rumah dengan diberikan tugas untuk dikerjakan. Orang tua pun diminta untuk mendampingi dan membantu anak selama belajar di rumah.

Inilah alasan tentang pentingnya keterlibatan orangtua selama anak usia dini belajar dari rumah. Menurut
Diadha (2015) keterlibatan orangtua dalam pendidikan anak akan memberikan keuntungan tidak hanya bagi orang tua, namun juga akan memberikan keuntungan bagi anak maupun sekolah itu sendiri. Morrison (dalam Santikko \& Mariyati, 2019) mengatakan bahwa keterlibatan orang tua adalah suatu proses dimana para orangtua menggunakan segala kemampuannya, guna keuntungannya sendiri dan anak-anaknya, serta program yang dijalankan itu sendiri.

Penelitian Cotton \& Wikelund (dalam Akbar, 2017) menjelaskan bahwa semakin intensif keterlibatan orangtua dalam pendidikan anak maka efek dalam prestasi akademis anak juga semakin positif. Hill \& Taylor (dalam Amini 2015) menunjukan bahwa keterlibatan orang tua dapat meliputi: memelihara arah kemajuan anak, sering berkomunikasi dengan guru, memastikan bahwa anak-anak menikmati tantangan, kelas pembelajaran yang baik, mengarahkan anak untuk memiliki motivasi berprestasi tinggi di sekolah. Penelitian Hoover-Dempsey \& Sandler (dalam Akbar 2017) menunjukkan hampir dapat dipastikan bahwa pada setiap kondisi, keterlibatan orangtua dapat dicirikan sebagai variabel yang memampukan dan meningkatkan keberhasilan dalam pendidikan anak dibandingkan hanya sekedar sebagai pelengkap keberhasilan dalam pendidikan anak. Edy, dkk (2018) dalam penelitiannya pada PAUD mendapatkan bahwa keterlibatan orang tua secara aktif dapat membentuk disiplin anak daripada keterlibatan orang tua yang pasif.

Dengan demikian, uraian diatas menunjukan bahwa keterlibatan orang tua sebagai kunci utama suksesnya pelaksanaan proses pembelajaran anak dari rumah khususnya di masa pandemi covid-19. Alasannya, tugas guru yang 
semula mendampingi anak selama belajar di sekolah kemudian berubah dengan memberikan panduan belajar atau tugas yang selanjutnya diteruskan oleh orang tua kepada anak di rumah. Dengan begitu, bagaimana keterlibatan orang tua dalam mendampingi anak belajar menjadi penting diketahui agar supaya bentuk-bentuk keterlibatan yang diberikan tepat dan berguna disaat anak diarahkan, dibimbing dan dibantu saat mengerjakan tugas-tugas sekolah dengan baik. Anak yang terbantukan dalam mengerjakan tugas belajar dapat menciptakan suasana belajar yang positif bagi anak.

Tujuan dari penelitian ini adalah bagaimana keterlibatan orang tua dalam mendampingi anak usia dini melakukan pembelajaran selama belajar dari rumah di masa pandemi covid-19 serta bentukbentuk keterlibatan orang tua dalam proses mendampingi anak belajar di rumah. Manfaat penelitian adalah orangtua menyadari betapa pentingnya keterlibatan orangtua dalam proses belajar anak selama di rumah dan mengenali bentuk-bentuk keterlibatannya. Dengan demikian, orangtua dapat meningkatkan kualitas dan intensitasnya dalam keterlibatan belajar anak di rumah selama masa pandemi covid-19.

\section{Tinjauan Literatur Belajar}

Belajar merupakan suatu proses utama dalam setiap usaha pendidikan. Konsep dasar belajar merupakan kegiatan yang berproses dalam memakai unsur yang sangat fundamental dalam penyelenggaraan setiap jenis dan jenjang pendidikan. Belajar bukan hanya semata-mata tentang bagaimana kita menghafal atau mengumpulkan fakta-fakta terkait materi dalam pelajaran (Isti'adah, 2020). Namun belajar merupakan suatu proses aktivitas mental yang dilakukan untuk memperoleh suatu perubahan tingkah laku yang bersifat positif dan melalui latihan atau pengalaman yang menyangkut aspek kepribadian secara fisik maupun psikis (Setiawan, 2017).

Secara garis besar, Hakim (2000) mendefenisikan belajar sebagai proses peningkatan kualitas dan kuantitas tingkah laku seseorang yang terlihat dengan bertambahnya kualitas dan kuantitas kemampuan orang tersebut dalam berbagai bidang. Suardi (2018) menyimpulkan bahwa belajar merupakan suatu perubahan dalam diri seseorang yang dapat dinyatakan dengan adanya penguasaan pola sambutan yang baru, berupa pemahaman, keterampilan dan sikap sebagai hasil proses dan hasil pengalaman yang dialami.

Berdasarkan kajian di atas dapat disimpulkan bahwa belajar merupakan suatu proses mengalami dan proses merubah dalam kaitannya untuk meningkatkan kualitas dan kuantitas kemampuan maupun keterampilan seseorang.

\section{Pembelajaran}

Proses pembelajaran pada hakekatnya dapat menjadi wahana penting dalam menganalisis sekaligus memecahkan masalah. Dalam penyelenggaraan pembelajaran kajian dan penelusuran terhadap paradigma yang melandasi dan menjadi pola adalah hal yang penting. Kebanyakan dari apa yang kita miliki, didasari dari hasil pembelajaran kita sejak usia balita. Hal ini tentu saja menegaskan bahwa institusi pertama dan utama dalam hal pembelajaran adalah keluarga. Orang tua menjadi guru pertama yang mengajar dan mendidik anak dalam proses hidupnya, menjadikan anak sebagai pribadi mandiri dalam menghadapi proses hidup.

Pihak lain, yakni guru, teman, dan lain-lain, hanya memberikan pendampingan dalam upaya pembelajaran. Istilah pembelajaran sendiri sangat berhubungan 
dengan belajar dan mengajar. Belajar dapat terjadi tanpa ada guru. Namun mengajar tentu meliputi segala kegiatan yang guru lakukan di kelas agar proses pembelajaran berjalan lancar, beretika, dan membuat siswa merasa nyaman dan tertarik untuk menjadi bagian dari aktivitas tersebut. Bahkan secara alamiah akan mencoba dan berupaya untuk mengimplementasikan kurikulum dalam kelas (Suardi, 2018). Pembelajaran merupakan proses interaksi antara peserta didik dan sumber belajar, dimana terdapat bantuan yang diberikan pendidik agar dapat terjadi proses perolehan ilmu dan pengetahuan (Darmadi, 2017).

\section{Keterlibatan Orang Tua dalam Pembelajaran}

Orang tua merupakan manusia dewasa yang pertama kali dilihat anak sejak masa kecil. Layaknya sebuah anugerah yang diberikan, orang tua wajib bersyukur, memelihara, menjaga, mengasuh dan mendidik dengan baik. Bimbingan dan pendidikan dari orang tua dapat dioptimalkan dengan pengajaran dan pengalaman dalam kehidupan sehari-hari. Pemikiran, emosi, dan perilaku orang tua merupakan model yang kemudian diadaptasi oleh anak dalam hal berfikir, berekspresi, dan berperilaku (Kristiyani, 2020).

Dalam mendidik anak untuk menjadi seseorang yang berhasil, maka keterlibatan orang tua merupakan hal yang paling efektif. Beberapa penelitian telah menunjukkan manfaat dari keterlibatan orang tua dalam proses pendidikan anak dalam meningkatkan prestasinya. Smit et al (dalam Kristiyani, 2020) menyampaikan bahwa keterlibatan orang tua dalam pendidikan anak merupaka bentuk dukungan orang tua terhadap anaknya, baik di rumah maupun di sekolah. Menurut Wong (dalam Lestari, 2016) keterlibatan orang tua adalah suatu bentuk ketertarikan, pengetahuan, dan kesediaan untuk berperan aktif dalam aktivitas anak setiap hari.

Keterlibatan orang tua dalam dunia pendidikan memiliki defenisi yang bervariasi, dimulai dari komunikasi orang tua dengan guru, partisipasi orang tua dalam kegiatan sekolah, bantuan orang tua dalam tugas-tugas anak (Kristiyani, 2020). Keterlibatan orang tua ini akan menjadikan orang tua lebih paham mengenai apa yang dipelajari anak serta dapat mengetahui apakah anak dapat mengikuti kegiatan pembelajaran yang berlangsung.

\section{Bentuk-bentuk Keterlibatan Orang Tua dalam Pembelajaran}

Epstein, dkk (dalam Amini, 2015) mengidentifikasi bentuk-bentuk keterlibatan orang tua dan strategi yang dapat dilakukan guru untuk mengembangkan kerja sama, antara lain: 1) tugas orang tua, dimana orang tua terlibat dalam segala kegiatan pendidikan anak; 2) Komunikasi, dimana adanya komunikasi aktif antara anak dan orang tua dapat meningkatkan kesehatan dan perkembangan anak; 3) relawan, merupakan keterlibatan orang tua dalam bentuk dukungan kepada sekolah dan aktivitasaktivitas yang terjadi di sekolah; 4) Belajar di runah, merupakan bentuk keterlibatan orang tua yang memperhatikan dan membantu anak belajar di rumah seperti mengerjakan tugas-tugas, dan juga membacakan buku; 5) pengambilan keputusan, merupakan keterlibatan sebagai perwujudan rasa memiliki orang tua terhadap lembaga pendidikan tempat anak bersekolah; 6) Kerjasama dengan masyarakat, merupakan keterlibatan yang menghubungkan orant tua, anak, guru, dan masyarakat secara bersama-sama demi meningkatkan kualitaas sekolah, seperti layanan kesehatan, rekreasi, dan lainnya.

Bentuk keterlibatan orang tua dalam pembelajaran anak juga di kemukakan 
KETERLIBATAN ORANG TUA DALAM PEMBELAJARAN ANAK USIA DINI SELAMA BELAJAR DARI RUMAH DI MASA PANDEMI COVID-19

oleh Hornby (dalam Retnaningtya \& Paramitha, 2015) yakni terdiri dari dua dua piramida yang menggambarkan tingkat kebutuhan orang tua (parental needs) dan tingkat kontribusi orang tua (parental contribution). Tingkat kebutuhan orang tua (parental needs) terdiri dari: 1) Support (dukungan), menjelaskan bahwa orang tua juga membutuhkan dukungan, seperti halnya melakukan pertemuan rutin orang tua dan guru dalam membahas perkembangan anak. 2) Education (pendidikan), orang tua juga membutuhkan pendidikan dimana tujuan akhirnya adalah untuk mendukung dan meningkatkan kemampuan dan keterampilan yang dimiliki oleh anak, serta untuk membentuk perilaku serta karakter anak. 3) Liaison (kepenghubungan), menjelaskan bahwa hubungan antara orang tua dan guru adalah penting dan sangat dibutuhkan, terlebih dalam hal saling berdiskusi terkait perkembangan anak di sekolah hingga apa saja yang dibutuhkan anak di ruman. 4) Communication (komunikasi), proses berkomunikasi dengan guru merupakan cara orang tua dalam memperoleh informasi terkait perkembangan anak dalam proses pendidikannya.

Sedangkan tingkat kontribusi orang tua terdiri dari: 1) Policy (kebijakan), dimana pada tingkatan ini jarang sekali orang tua mau terlibat dalam kebijakan sekolah, seperti mau menjadi anggota persatuan orang tua murid. 2) Resource (sumber belajar), orang tua harus bisa menjadi sumber belajar, agar dapat membantu sekolah dan guru, karena orang tua lebih memahami kondisi anaknya, danmampu memberikan efek balik positif bagi orang tua. 3) Collaboration (kolaborasi, orang tua dapat berkolaborasi dengan guru melalui program belajar di rumah demi memperkuat pembelajaran di sekolah. 4) Information (informasi), orang tua dapat memberikan informasi yang berhubungan dengan anak, demikian juga dengan pihak sekolah, sehingga perkembangan anak dapat terus terpantau.

\section{Dampak keterlibatan Orang Tua dalam Pembelajaran}

Orang tua sebagai guru pertama bagi anak, tentu saja dan sewajarnya harus dapat membantu dan memberikan dampak bagi perkembangan dan pertumbuhan anak. Dalam hal perilaku, dampak yang ditimbulkan dari keterlibatan orang tua dalam pendidikan anak adalah: 1) Anak memiliki kepercayaan diri yang tinggi, ketika mendapat dukungan dari keluarga maupun sekolah; 2) Menurunkan perilaku antisosial dan perilaku kekerasan anak; 3) Berkembangnya sikap dan perilaku anak yang lebih positif.

Dalam hal prestasi, keterlibatan orang tua juga memberikan dampak yaitu: 1) Anak akan lebih rajin; 2) Anak akan lebih disiplin saat hadir dalam kegiatan sekolah; 3) prestasi anak akan meningkat (Amini, 2015). Retnaningtya \& Paramitha (2015) juga menjelaskan bahwa ketika orang tua terlibat dalam proses pembelajaran anak, maka akan memberikan dampak antara lain: 1) anak akan mendapatkan treatment yang tepat. 2) orang tua terfasilitasi melakukan tanggungjawabnya. 3) orang tua mendapat tambahan pengetahuan. 4) orang tua dapat berbagi pengetahuan yang baru dengan anak. 5) mempererat hubungan anak dengan orang tua.

Keterlibatan orang tua dalam proses pembelajaran hidupnya akan membuat anak merasa diperhatikan, dilindungi, dan didukung dalam setiap gerak-gerik hidupnya. Hal ini akan mendukung perkembangan anak dalam mencapai kualitas hidup yang optimal.

\section{Metode Penelitian}

Penelitian ini menggunakan pendekatan kualitatif dengan metode studi kasus pada 10 orang tua (ayah atau ibu) 
yang memiliki anak usia dini di PAUD Rafflesia Arnolis, Kayu Tiga, Negeri Soya, Kota Ambon. Data diperoleh melalui wawancara dan dokumentasi. Wawancara dilakukan terhadap orang tua siswa siswi PAUD Rafflesia Arnolis, siswa siswi yang berumur 5-6 tahun, kepala Sekolah dan para guru sedangkan dokumentasi diperoleh dari dokumen sekolah dan juga saat melakukan wawancara melalui video call dengan orang tua saat belajar anak berlangsung. Alasan penggunaan teknik wawancara dan dokumentasi sebab adanya larangan untuk berinteraksi secara dekat dengan orang lain (social physical distancing) selama pandemi covid-19.

Studi Kasus ialah suatu serangkaian kegiatan ilmiah yang dilakukan secara intensif, terinci dan mendalam tentang suatu program, peristiwa, dan aktivitas, baik pada tingkat perorangan, sekelompok orang, lembaga, atau organisasi untuk memperoleh pengetahuan mendalam tentang peristiwa tersebut (Rahardjo, 2017). Salah satu alasan menggunakan pendekatan kualitatif adalah pengalaman para peneliti dimana metode ini dapat digunakan untuk menemukan dan memahami apa yang tersembunyi dibalik fenomena yang kadangkala merupakan sesuatu yang sulit untuk dipahami secara memuaskan (Rahmat, 2009).

\section{Hasil}

Berdasarkan hasil wawancara dengan orang tua diketahui bahwa selama pandemi covid-19 belajar anak di rumah dalam bentuk mengerjakan tugas sekolah. Tugas dikirimkan oleh sekolah melalui group orang tua dan sekolah yang dibentuk di aplikasi whatshap. Tugas tersebut atau biasa disebut LKA (Lembar Kerja Anak) akan dicetak (print) sendiri oleh orang tua, kemudian diberikan kepada anak untuk dikerjakan. Tugas sekolah ini akan dikerjakan per hari sesuai hari dan tanggal yang sudah tertera pada LKA, yakni Senin sampai Jumat. Hal ini disesuaikan dengan jadwal sekolah anak seperti biasanya dilaksanakan. Tugas yang telah dikerjakan dikumpulkan orang tua dan disatukan pada satu file map yang akan diserahkan kepada guru di akhir semester atau saat dimintakan. Orang tua dibekali sekolah dengan memberikan RPPH, yaitu Rencana Pelaksanaan Pembelajaran Harian. RPPH merupakan panduan yang berisi langkah-langkah yang harus disiapkan, diajarkan dan diterapkan oleh orang tua kepada anak saat mengerjakan tugas sekolah. RPPH selalu berubah-ubah menyesuaikan dengan tugas yang akan dikerjakan anak. Selain itu, orang tua harus mengambil video dan foto anak saat sedang mengerjakan tugasnya dan bagaimana keterlibatan orang tua dalam mengajarkan anak sesuai dengan RPPH yang diberikan. Video dan foto tersebut akan dkirimkan kepada guru melalui group whatshapp sekolah.

Selama belajar dari rumah, anak lebih banyak didampingi oleh ibu daripada ayah. Dengan alasan yang bervariasi seperti ayah sebagai pekerja, ayah yang bekerja jauh di luar daerah atau anak yang lebih merasa nyaman kalau diajarkan oleh ibunya. Lain halnya dengan anak yang memiliki ayah dan ibu yang bekerja, maka peran untuk terlibat dalam belajar anak di rumah adalah kakek atau nenek dan atau anggota keluarga lain yang serumah dengan anak. Sebelum belajar di rumah mulai, orang tua atau anggota keluarga lain yang terlibat dalam mendampingi anak belajar akan melakukan beberapa persiapan, dimulai dengan persiapan fisik anak, misalnya mandi dan berpakaian. Kemudian menyiapkan ruangan, alat belajar seperti pensil, kertas, pewarna dan juga bahan penunjang tugas anak misalnya stik dan kartu huruf suku kata. Kelengkapan penting yaitu $\mathrm{Hp}$ untuk 
KETERLIBATAN ORANG TUA DALAM PEMBELAJARAN ANAK USIA DINI SELAMA BELAJAR DARI RUMAH DI MASA PANDEMI COVID-19

melakukan rekaman atau mengambil video saat anak belajar sebagai bukti harian kepada sekolah. Persiapan lainnya adalah orang tua mempersiapkan diri sendiri dengan cara mempelajari materi ajar anak. Orang tua juga melakukan komunikasi dengan pihak sekolah untuk penjelasan pengerjaan tugas yang diberikan.

Dalam wawancara terdapat beberapa orang tua yang menyatakan bahwa lebih baik anak belajar di sekolah daripada di rumah sebab orang tua merasa lebih sulit mengajarkan anak untuk memahami tugas sekolah. Tantangan lainnya adalah mood atau suasana hati anak yang berubahubah, anak mulai mengalami kebosanan di rumah dan lebih senang jika belajar bersama dengan teman. Hal ini juga diungkapkan oleh anak dalam wawancara bahwa mereka lebih senang jika belajar bersama dengan temannya di sekolah. Belajar secara mandiri di rumah membuat anak menjadi kurang tertantang. Anak pun mulai mengalami kebosanan dan mengalihkan rasa bosan tersebut dengan melakukan hal-hal yang menyenangkan bagi dirinya sendiri, seperti olahraga, main boneka-boneka. Cara lain juga dengan menyalurkan hobi seperti menggambar dan mewarnai.

Pihak sekolah selama anak belajar dari rumah tetap aktif menyiapkan materi ajar, LKH dan RPPH yang akan dikirimkan kepada orang tua dan anak. Pihak sekolah pun melakukan komunikasi dengan orang tua melalui telepon, video call, dan chat melalui whatshapp. Hal lainnya adalah para guru mengunjungi rumah masing-masing anak guna menanyakan perkembangan belajar anak dari para orang tua. Dalam video call pihak sekolah merangkainya dengan cara membuat kelompok yang terdiri dari beberapa orang tua. Tujuannya agar pihak sekolah dan sesama para orang tua akan saling berbagi pengalaman selama terlibat mendampingi anak belajar dari rumah.

\section{Pembahasan}

Situasi pandemi covid-19 menuntut adanya perubahan dan penyesuaian diri anak dengan gaya belajar yang baru. Setiawan (2017) menjelaskan bahwa belajar merupakan suatu proses aktivitas mental yang dilakukan untuk memperoleh suatu perubahan tingkah laku yang bersifat positif dan melalui latihan atau pengalaman yang menyangkut aspek kepribadian secara fisik maupun psikis. Dalam penelitian ini, perubahan dan penyesuaian anak selama belajar dari rumah dilakukan seperti mengerjakan tugas sekolah di rumah, adanya perubahan jadwal belajar yang tidak seperti biasanya sewaktu sekolah normal, anak mengalami kebosanan selama melakukan belajar dari rumah, dan anak lebih banyak waktu untuk nonton televisi ataupun main gadget. Namun dalam mengisi kebosanan, ada juga anak yang menyalurkan hobinya seperti menggambar dan mewarnai.

Perubahan dan penyesuaian ini menuntut bagaimana keterlibatan orang tua diperankan, antara lain: pertama, anak memerlukan keterlibatan orang tua secara total dalam mendampingi. Keterlibatan secara total dimaksudkan bahwa orang tua bukan sekedar menjalankan fungsi untuk memonitor tugas sekolah yang dikerjakan atau memotivasi anak untuk belajar tetapi orang tua harus menyiapkan dirinya sendiri untuk menjadi 'guru' di rumah bagi anak selama melakukan proses pembelajaran. Berfungsi sebagai 'guru' di rumah mengharuskan orang tua untuk membekali diri dengan mempelajari materi ajar anak, LKA, mempelajari metode belajar yang tepat serta mempedomani RPPH yang diberikan guru dari sekolah. Selain itu, keterlibatan orang tua secara total itu penting sebab 
perlu terjalinnya sinergi antara orang tua, anak dan sekolah (pendidik) untuk mengoptimalkan potensi belajar anak dalam mencapai prestasi akademik seperti membaca, berhitung, dan menulis namun juga bertumbuh dan berkembang menjadi pribadi yang mandiri, berkarakter dan kreatif.

Kedua, orang tua adalah sumber belajar anak. Darmadi (2017) menjelaskan bahwa pembelajaran merupakan proses interaksi antara peserta didik dan sumber belajar, dimana terdapat bantuan yang diberikan pendidik agar dapat terjadi proses perolehan ilmu dan pengetahuan. Sebagai sumber belajar anak, orang tua berkewajiban untuk menutrisi intelektualnya dengan berbagai informasi dan ilmu pengetahuan melalui aktivitas seperti membaca buku, mengikuti webinar, mengikuti video belajar atau video kegiatan kreativitas anak. Ini bisa menjadi sumber inspiratif bagi orang tua dalam memberikan kegiatan tambahan mengisi rasa bosan selama anak di rumah. Ketiga, orang tua harus menyediakan waktu. Waktu adalah penting sebab dengan waktu seluruh tujuan pembelajaran yang harus dicapai anak terpenuhi. Orang tua dengan tingkat kesibukan yang tinggi menjadikan waktu belajar anak terlewati begitu saja tanpa pendampingan. Pendampingan yang diberikan oleh orang tua di rumah dapat meningkatkan motivasi belajar anak selain bimbingan dari seorang guru dari la belajar, dengan motivasi yang kuat seseorang sanggup bekerja ekstra keras dalam pencapaian sesuatu (Ambaryanti, 2013).

Oleh sebab itu, bagaimana keterlibatan orang tua diperankan selama anak belajar di rumah, harus juga didukung dengan bentuk-bentuk keterlibatan orang tua, antara lain:

1. Komunikasi orang tua dan guru. Dalam tahap ini orang tua dapat mengkomunikasikan tentang tugas sekolah anak, perkembangan belajar anak, kendala anak dalam mengerjakan tugas sekolah dan kondisi psikis anak selama belajar di rumah. Komunikasi ini dapat disampaikan melalui telepon, video call, atau group sekolah pada whatsapp. Epstein, dkk (2002) menyebutkan bahwa bentuk keterlibatan orang tua berupa komunikasi antara rumah dan sekolah atau sebaliknya diharapkan mampu mengkomunikasikan tentang program sekolah maupun pendidikan, perkembangan dan kesehatan anak guna meningkatkan kerjasama dan pemahaman orang tua dan guru tentang anak.

2. Membantu anak belajar di rumah. Situasi pandemi covid-19 menutut orang tua menjadi 'guru' di rumah. Ini berarti orang tua terlibat penuh dalam aktivitas pembelajaran anak seperti mengerjakan tugas sekolah, menyiapkan ruangan belajar, peralatan belajar anak dan menyediakan sumber belajar bagi anak. Epstein dkk (2002) menjelaskan bahwa bentuk keterlibatan orang tua dalam pembelajaran di rumah dimaksudkan sebagai kegiatan orang tua dalam membantu anak belajar di rumah seperti membantu anak mengerjakan tugas di rumah, membacakan buku cerita yang mendidik, dan sebagainya.

3. Menyediakan fasilitas pembelajaran. Selama belajar di rumah anak membutuhkan fasilitas pembelajaran. Fasilitas pembelajaran merupakan semua yang diperlukan dalam proses belajar mengajar baik yang bergerak maupun yang tidak bergerak agar pencapaian tujuan pendidikan dapat berjalan dengan lancar, teratur, efektif dan efisien (Arikunto \& Yuliana, 2008). Fasilitas dapat be- 
rupa, ruang belajar, alat-alat belajar, buku pelajaran, gambar atau video.

Selain itu, selama anak belajar dari rumah ada beberapa hal positif yang tercipta antara orang tua dan anak, antara lain: pertama, adanya kelekatan orang tua dan anak. Kelekatan merupakan suatu ikatan emosional yang kuat yang dikembangkan anak melalui interaksinya dengan orang yang mempunyai arti khusus dalam kehidupannya, biasanya orang tua (McCartney \& Dearing 2002, dalam Eliasa 2011). Artinya, belajar bersama orang tua dapat memberikan kesempatan besar kepada anak untuk mengalami kedekatan yang bukan saja fisik namun juga secara emosional. Selain itu dalam penelitian Permatasari (2021) menemukan bahwa kuantitas waktu yang dimiliki untuk keluarga karena kebijakan social and physical distancing menjadi lebih banyak jika dibandingkan sebelum social and physical distancing. Waktu belajar dan bermain dengan anak lebih banyak. keintiman keluarga dibangun dari kemampuan memahami peran masingmasing, memahami diri sendiri, dan menyampaikan serta menerjemahkan pesan dengan baik. Baik itu ayah atau suami, ibu atau istri, dan anak.

Kedua, orang tua dapat mengikuti dan tahu tentang perkembangan belajar anak. Perlu diketahui bahwa aktivitas belajar yang dilakukan bersama orang tua akan menjadi pengalaman menarik yang dimiliki anak dan pengalaman ini membantu anak untuk berkembang secara fisik, emosional, sosial dan juga intelektual. Kesempatan ini akan membantu pertumbuhan dan perkembangan anak dalam menyelesaikan tugas perkembangannya di tengah masa pandemi covid-19; dan ketiga, orang tua diperkaya secara intelektual dan kreatif selama menjadi 'guru' bagi anak di rumah. Artinya, orang tua ikut serta belajar baik dalam mempersiapkan diri sebelum mengajar atau sekedar menambah pengetahuan, seperti membaca buku. Penting untuk orang tua memperkaya pengetahuannya sebab ketika anak belajar dirumah dengan orangtua, belum tentu semua orangtua paham tentang psikologi anak, cara mengatasi situasi hati anak yang tidak menentu, cara menstimulus anak, cara memberikan reward and punishment dengan baik dan paling utama adalah cara mengajar anak dengan baik sesuai dengan konsep psikologi anak begitu penting peran orangtua dirumah (Ulfah \& Na'imah, 2020).

\section{Simpulan}

Dari uraian diatas dapat disimpulkan beberapa hal, antara lain: 1) selama belajar di rumah, anak memerlukan keterlibatan orang tua secara total untuk mendampingi dan membantunya. Tentunya orang tua harus menyiapkan dirinya sendiri untuk menjadi 'guru' di rumah bagi anak dengan berbagai persiapan, mulai dari membaca buku, mengikuti webinar, mengikuti video belajar atau video kegiatan kreativitas anak guna menutrisi intelektualnya dengan berbagai informasi dan ilmu pengetahuan dan juga bisa menjadi sumber inspiratif dalam memberikan kegiatan tambahan mengisi rasa bosan selama anak di rumah; 2) dengan belajar di rumah, terdapat hal positif yang tercipta antara orang tua dan anak, seperti adanya kelekatan orang tua dan anak, orang tua dapat mengikuti dan tahu tentang perkembangan belajar anak dan orang tua diperkaya secara intelektual dan kreatif selama menjadi 'guru' bagi anak di rumah; dan 3) bentuk-bentuk keterlibatan orang tua, antara lain: komunikasi orang tua dan guru, membantu anak belajar di rumah dan menyediakan fasilitas pembelajaran.

\section{Saran dan Rekomendasi}


1. Saran: Dalam melakukan penelitian terhadap anak usia dini harus dapat memperhatikan aspek lain sebagai faktor yang ikut mempengaruhi seperti perkembangan anak, faktor pendidikan orang tua, lingkungan sosial anak, dan sekolah anak.

2. Rekomendasi: Penelitian ini masih banyak keterbatasannya, untuk itu peneliti lain pada bidang yang sama atau penelitian yang bersifat kolaborasi dapat menggali banyak hal tentang keterlibatan orang tua dalam proses belajar anak.

\section{Keterbatasan Penelitian}

Adapun keterbatasan dalam penelitian ini adalah situasi pandemi covid-19 mengharuskan peneliti menjaga jarak selama mengumpulkan data seperti saat melakukan observasi proses belajar anak di rumah, melakukan wawancara dengan orang tua serta melakukan dokumentasi. Semuanya dilakukan secara daring dan ada beberapa yang dilakukan secara langsung seperti melakukan wawancara dengan guru, kepala sekolah, dokumen LKA dan RPPH.

\section{Ucapan Terima Kasih}

Banyak pihak yang boleh mendukung terlaksananya penelitian ini. Untuk itu, ucapan terima kasih kami sampaikan kepada; 1) Kepala Sekolah PAUD dan para guru Rafflesia Arnolis Kayu Tiga Ambon; 2) Para orang tua siswa PAUD Rafflesia Arnolis Kayu Tiga Ambon; 3) tim redaksi jurnal Institutisio yang memberikan kesempatan dan masukan demi peningkatan kualitas penelitian ini.

\section{Pustaka Acuan}

Aji R H S. 2020. Dampak Covid-19 pada Pendidikan di Indonesia: Sekolah, Keterampilan, dan Proses Pembelajaran. SALAM; Jurnal
Sosial \& Budaya Syar-i FSH UIN Syarif Hidayatullah Jakarta Vol. 7 No. 5 (2020), pp. 395-402

Akbar Z. 2017. Program peningkatan keterlibatan orangtua melalui kegiatan seni pada anak usia dini (art programs to increase parent involvement in early childhood). Jurnal Sarwahita Vol. 14 No. 01, hal 53-60.

Ambaryanti R. 2013. Hubungan intensitas pendampingan belajar orang tua dengan kualitas hasil belajar siswa di ra al-islam mangunsari 02 semarang tahun pelajaran 2011/2012. Indonesian Journal of Early Childhood Education Studies, IJECES 2 (2) (2013), page 43-49. http://journal.unnes.ac.id/sju/index.p $\mathrm{hp} /$ ijeces

Amini Mukti. 2015. Profil Keterlibatan Orang Tua dalam Pendidikan Anak Usia TK. Jurnal Ilmiah Visi PPTK PAUDNI, Vol 10, No. 1, hal 9-20.

Arikunto S \& Yuliana L. 2008. Manajemen Pendidikan. Yogyakarta: Aditya Media.

Darmadi H. Pengembangan Model dan Metode Pembelajaran dalam Dinamika Belajar Siswa. Yogyakarta: Deepublish.

Diadha R. 2015. Keterlibatan orang tua dalam pendidikan anak usia dini di taman kanak-kanak. Edusentris, Jurnal Ilmu Pendidikan dan Pengajaran, Vol. 2 No. 1, hal 61-71

Edy, CH M, Sumantri M S \& Yetti E. (2018). Pengaruh keterlibatan orang tua dan pola asuh terhadap disiplin anak. Jurnal Pendidikan Usia Dini. Vol 12 Edisi 2 Hal 221-230.

Eliasa E I. 2011. Pentingnya Kelekatan Orangtua dalam Internal Working Model untuk pembentukan Karakter Anak (Kajian Berdasarkan Teori Kelekatan dari John Bowlby). Pusat 
Studi Pendidikan Anak Usia Dini Lembaga Penelitian UNY. Dikutip dari:

http://staffnew.uny.ac.id/upload/1323 18571/penelitian/Microsoft+Word++ PENTINGNYA+KELEKATAN+O RANG+TUA+DALAM+INTERNA L+WORKING+MODEL+UNTUK+ PEMBENTUKAN+KARAKTER+A NAK.pdf

Epstein J L, Sanders M G, Simon B S. at all. 2002. School, family, and community partnerships, your handbook for action: Second edition. Thousand Oaks, California: Corwin Press

Gunarsa, S. D. (2000). Psikologi perkembangan. Jakarta: PT BPK Gunung Mulia

Hakim Thursan. Drs. (2000). Belajar Secara Efektif. Jakarta: Puspa Swara.

Isti'adah Feida Noorlaila, M.Pd. (2020). Teori-Teori Belajar Dalam Pendidikan. Tasikmalaya: Edu Publisher.

Kristiyani, T. (2020). Self-Regulated Learning: Konsep, Implikasi dan Tantangannya Bagi Siswa di Indonesia. Yogyakarta: Sanata Dharma University Press.

Lestari, S. (2016). Psikologi Keluarga: Penanaman Nilai dan Penanaman Konflik Dalam Keluarga. Jakarta: Prenada Media.

Mulyana, D. (2006). Penelitian kualitatif paradigma baru ilmu komunikasi dan ilmusosial lainnya. Bandung, Indonesia: PT Rosdakarya.

Menteri Pendidikan dan Kebudayaan Republik Indonesia. Surat Edaran Nomor 4 Tahun 2020 Tentang Pelaksanaan Kebijakan Pendidikan Dalam Masa Darurat Penyebaran Coronavirus Disease (Covid-19). Dikutip dari: https://jdih.kemdikbud.go.id/arsip/SE
\%20Menteri\%20Nomor\%204\%20Ta hun\%202020\%20cap.pdf

Nurkolis. (2003). Manajemen Berbasis Sekolah: Teori, Model, dan Aplikasi. Jakarta: Grasindo.

Permatasari A N, Inten N D, Wiliani \& Widiyanto N K. 2021. Keintiman Komunikasi Keluarga saat Social Distancing Pandemi Covid-19. Jurnal Obsesi: Jurnal Pendidikan Anak Usia Dini, Vol 5, Issue 1 (2021) Pages 346-359

Rahmat P S .(2009). Penelitian Kuantitatif. Equilibrium, Vol 5, No 9, hal 1-8.

Rahardjo M. (2017). Studi kasus dalam penelitian kualitatif: konsep dan prosedurnya. Program Pascasarjana. Universitas Islam Negeri Maulana Malik Ibrahim Malang.

Retnaningtya Mega Silvia \& Paramitha Pramesti Pradna. 2015. Keterlibatan Orang Tua Dalam Pendidikan Anak Di TK Anak Ceria (Parental Involement In Education At TK Anak Ceria). Jurnal Psikologi Pendidikan dan Perkembangan, Vol 4, No. 1, hal 9-17.

Santikko I \& Mariyati L I. 2019. Bentuk keterlibatan orang tua pada anak tk yang berprestasi melukis parental involvement in kindergarten who have achievement in drawing. Jurnal Psikologi Poseidon Vol 2, No 1, hal 58-66

Satrianingrum A P \& Prasetyo I. (2021). Persepsi Guru Dampak Pandemi Covid-19 terhadap Pelaksanaan Pembelajaran Daring di PAUD. Jurnal Obsesi: Jurnal Pendidikan Anak Usia Dini. Vol 5 Issue 1 (2021) Pages 633-640.

Setiawan M. Andi, M.Pd. (2017). Belajar dan Pembelajaran. Ponorogo: Uwais Inspirasi Indonesia. 
74

Jane Gresia Akollo, Meike Elsa Toisuta

Suardi Moh. (2018). Belajar dan Pembelajaran. Yogyakarta: Deepublish.

Ulfah, M., \& Na'imah. (2020). Peran Keluarga dalam Konsep Psikologi Perkembangan Anak Usia Dini. Aulad: Journal on Early Childhood, $3(1), 20-28$. 